Volume 7 Issue 1, March 2020

Nationally Accredited Journal,

Decree No. B/4130/E5/E5.2.1/2019

\title{
Relevance Of Justice Value In Legal Protection Of Debtor In The Political Law Of Bankruptcy
}

\section{Budisidhabhiprodjo ${ }^{1}$}

\begin{abstract}
In its development the business world requires the provision of capital loan services. However, the development of the need for capital in the business world is not balanced with protection for debtors. The existence of Articles 55 and 56 of Act Number 37 of 2004 concerning Bankruptcy and Suspension of Debt Payment Obligations, the position of debtor protection in the bankruptcy undertaken by a separatist creditor against the creditor becomes weak, this is due to the absence of legal remedies that can be done by the dbitur when bankruptcy has been declared effective against him. Therefore the issues that will be discussed in this journal are the legal protection system for debtors in bankruptcy politics, weaknesses in the legal protection system for debtors in bankruptcy political politics, and issues related to finding solutions through reforming the legal protection system for debtors in bankruptcy politics.

The purpose of this research is to analyze the legal protection system for debtors in bankruptcy law politics; to analyze the weaknesses of the legal protection system for debtors in bankruptcy law politics; to find a solution through reforming the legal protection system for debtors in bankruptcy law politics.

The research method used in this paper is a normative juridical approach. As for the research that has been done, it can be concluded that the existence of Article 55 and Article 56 of Act Number 37 of 2004 concerning Bankruptcy and Delaying Obligations of Debt Payment has resulted in injustice to debtors in the implementation of bankruptcy against debtors committed by creditors; So it is necessary to reform the implementation of debtor protection in the implementation of bankruptcy to debtors by the creditor by implementing a system of debtor protection in the implementation of bankruptcy to debtors based on Pancasila.

Keywords: Debtor, Justice Value, Legal Protection, Legal Politics, Bankruptcy
\end{abstract}

\section{Introduction}

In its development the business world is one of the cornerstones for the progress of a country's economy, therefore the progress of the business world is also highly expected in various countries. This is because business progress in a country can support economic growth and prosperity. Therefore healthy lending capital activities become an important instrument in the progress of the business world which also needs attention. Accounts receivable institutions with collateral are the realization of the basic idea. But not infrequently in the development of the world of capital lending and receivables often experience various problems, especially problems in terms of paying off debts by the debtor. So in order to overcome these problems, various legal regulations related to bankruptcy were born.

In Law Number 37 of 2004 concerning Bankruptcy and Deferral of Debt Payment Obligations, the understanding of creditors is a person who has a debt due to an agreement or law that can be collected in court. However, in the elucidation of Article 2 paragraph (1) of Law Number 37 of 2004 provides definitions referred to as creditors

\footnotetext{
${ }^{1}$ Lecturers Of Faculty Of Law, UNISSULA, Semarang email shidabiprojo@unissula.ac.id
} 
in this paragraph are both concurrent creditors, separatist creditors and preferred creditors. Specifically for separatist creditors and preferred creditors, they can file bankruptcy statements without losing the collateral rights over the property they have against the debtor's assets and their right to take precedence.

Even though creditors and debtors have a commitment, in reality the rights of separatist creditors are often detrimental to the debtor in terms of determining and implementing bankruptcy of a debtor in the world of dependable law in Indonesia. This problem occurs due to the provision of Article 55 of Law Number 37 of 2004 concerning Bankruptcy and Postponement of Obligations of Debt Payment, which states that by observing the provisions in Article 56, Article 57, and Article 58, each creditor holding a pledge, fiduciary guarantee, rights dependents, mortgages, or other collateral rights, can execute their rights as if bankruptcy did not occur.

This statement can clearly result in the execution of a one-sided execution by the creditor of the debtor even though the debtor has the ability to pay. This is further compounded by the existence of Article 56 of Law Number 37 of 2004 concerning Bankruptcy and Suspension of Debt Payment Obligations which states that after the statement of the debtor's bankruptcy is made by the creditor, there is a 90-day suspension of debt payment. This means that debtors who have been declared bankrupt by the creditors will incur losses due to the confiscation of various important assets and declared bankruptcy by the creditor, and must experience a 90-day legal uncertainty regarding the use of their assets.

In connection with the various explanations above, a number of issues can be formulated in this journal, these issues are related to issues that exist in the implementation of legal protection for debtors from separatist creditor rights related to bankruptcy executions carried out by creditors. separatist towards current debtors. As well as issues related to repositioning justice in the matter of implementing legal protection for debtors in the current bankruptcy law politics.

The research objectives related to this paper are: This research to analyze the legal protection system for debtors in bankruptcy law politics; This research to the weaknesses of the legal protection system for debtors in bankruptcy law politics; This research to find a solution through reforming the legal protection system for debtors in bankruptcy law politics.

\section{Research Method}

Research Method to used in the writing of this journal is the normative juridical approach, in which the discussion method used looks at the law in perspective of legislation, which is supported by field data.

\section{Discussion}

\subsection{Debtor Protection in Bankruptcy Politics Nowadays}

On its way after the establishment of the Bankruptcy Law No. 4 of 1998 is still felt many shortcomings and weaknesses and in line with the demands of community development, the provisions in Law No.4 of 1998 are considered not able to meet the 
legal needs of the community, so it is necessary to make changes set on October 18 2004 through Law No. 37 of 2004 concerning Bankruptcy and Suspension of Debt Payment Obligations.

Law No. 37 of 2004 concerning Bankruptcy and Deferral of Debt Payment Obligations (UUKPKPU) which were expected to be more comprehensive turned out to be not what many had expected, which did not change the principles of comprehensive bankruptcy but were only a tool to collect bad loans without taking into account the effects of bankruptcy. This is to the continuation of the company's global business in Indonesia and increase unemployment due to job loss. ${ }^{2}$

The current bankruptcy law can be a time bomb and a threat to companies that are operating well and existing and future investors in Indonesia because the UUKPKPU contains many weaknesses and loopholes that can be exploited by creditors and the company itself (debtors ) to bankrupt itself. ${ }^{3}$

The weaknesses are due to its hasty formation so that it does not produce an adequate set of legal rules. As a result there are many things that are not explicitly regulated, and ultimately lead to diverse interpretations.

With these weaknesses, it is easy for creditors to bankrupt companies using the Bankruptcy Law, such as or for example two creditors who have the smallest amount of credit can bankrupt large companies that are still solvent. In addition, if the debtor (company) is late for just one day to pay the debt to the creditor, the creditor can file for bankruptcy. This is very risky and dangerous for the business continuity of the two creditors whose debts are late paid by the debtor can be their conditions for bankruptcy. Even people who have one-dollar receivables can bankrupt the company. ${ }^{4}$ The main problem today, can be seen in Article 2 (paragraph 1) of Law Number 37 of 2004 concerning irrational bankruptcy requirements because the request for bankruptcy can be filed and the decision of bankruptcy by the Commercial Court can be imposed on debtors who are still solvent, (ie debtors whose assets are greater than the total debts). With such bankruptcy conditions, legal certainty and the objective of implementing a bankruptcy law that is fair will be very difficult to achieve. In addition, Law Number 37 of 2004 pays more attention to and protects the interests of the bankrupt creditors rather than the interests of the bankrupt debtor which should also be protected. ${ }^{5}$

The conditions for bankruptcy as referred to in Article 1 "Faillissements-Verordening", which came into force on November 1, 1906, even though it only gives the possibility to submit a bankruptcy request to a debtor in an inability (Van de voorziening in geval van onvermogen van kooplieden ) or not able to be real (kennelijk onvermogen) so it is in a state of stopping repaying its debts. That is, the debtor has been insolvent

\footnotetext{
${ }^{2}$ https://www.hlplawoffice.com/protection-law-balance-on-creditor-and-debitur-pailit/, accessed on 4 July 2019

${ }^{3}$ Loc.cit.

4 https://www.hukumonline.com/pusatdata/detail/320/node/19/undangundang-nomor-4-tahun1998/, accessed on 4 July 2019.

${ }^{5}$ Loc.cit.
} 
(greater than the liabilities of the assets and receivables), ${ }^{6}$ Whereas for debtors who are still solvents (smaller than their liabilities and assets), the Curator should ask the debtor to jointly find a solution to settle their obligations by improving management, one example is that the Curator and debtor conduct an independent audit to find out the debtor's problem so that the curator is not directly conduct asset acquisition from bankrupt debtors. ${ }^{7}$

\subsection{Issues that Exist in the Implementation of Legal Protection for Debtors in Bankruptcy Law Politics Today}

In Article 55 of Law Number 37 of 2004 Concerning Bankruptcy and Deferral of Obligations for Debt Payments, it is expressly stated that by observing the provisions in Article 56, Article 57, and Article 58, each creditor holding a lien, fiduciary guarantee, mortgage, or collateral rights over other material, can carry out the execution of their rights as if bankruptcy did not occur.

This article has made debtors vulnerable to bankruptcy by creditors, even though the debtor has the ability to repay his debt to the creditor. Then Article 56 of Law Number 37 of 2004 Concerning Bankruptcy and Deferral of Obligations for Debt Payments states that after the statement of the debtor's bankruptcy is made by the creditor, there is a 90-day suspension of debt payment.

This article clearly results in debtors who have been declared bankrupt by the creditor will suffer losses due to the confiscation of various important assets and the bankruptcy declared by the creditor, and must experience legal uncertainty for 90 days related to the use of the assets they have. This clearly has led to the disposition of justice in the implementation of the legal protection of debtors from the rights of separatist creditors in the case of bankruptcy in Indonesia.

The "cash" electronic mass media website states unequivocally that throughout 2019 there were 411 bankruptcy cases, which consisted of 297 PKPU cases and 194 bankrupt cases. This clearly shows that there has been a surge in bankruptcy cases in 2019, in 2017 there were 353 bankruptcy cases recorded, consisting of 238 PKPU cases and 115 bankruptcy cases. ${ }^{8}$

This situation clearly also causes the number of domestic companies to increase as well in 2019. Furthermore, the media "cash" also notes that the higher number of companies experiencing bankruptcy are manufacturing and property companies. The number of manufacturing companies that experienced bankruptcy cases consisted of 69 PKPU cases and 17 bankruptcy cases. While in the property sector there were 69 PKPU shirts and 22 bankruptcy cases. ${ }^{9}$ While the sector of the company that was the least experiencing bankruptcy issues in Indonesia in 2018 was information technology

\footnotetext{
${ }^{6}$ Geez. R. Soejartin, Commercial Law I and II, Publisher Pradnya Paramita, Jakarta, 2007, p. 263.

${ }^{7}$ Loc.cit

8 Anggar Septiadi, Around 2018, Number of Bankruptcy Cases Soared, accessed via kontan.co.id, on May 12, 2019

${ }^{9}$ LoC, cit.
} 
Volume 7 Issue 1, March 2020

Nationally Accredited Journal,

Decree No. B/4130/E5/E5.2.1/2019

companies, namely only $6 \mathrm{PKPu}$ cases and 3 bankruptcy cases. ${ }^{10}$ Then kontan.co.id states that most of the bankruptcy filed by separatist creditors against the debtor, not originating from the request for restructuring the debituary. ${ }^{11}$

This is clearly unfair for the debtor given the provisions related to the debtor bankruptcy based on the authority of the separatist creditors, which even though after the determination of the bankruptcy has been granted for no later than 20 days, the debtor is only given protection measures in the form of submission of a proposal for restructuring. However, if the debtor's restructuring proposal is rejected by the separatist creditor, the debtor cannot do much to protect the debtor's bankrupt position. So clearly this situation will significantly result in a debtor can experience losses and bankruptcy.

In addition to the problems as explained above, in the implementation of bankruptcy against debtors by separatist creditors, it can also be seen in Article 2 (paragraph 1) of Law Number 37 Year 2004 concerning the conditions of irrational bankruptcy because bankruptcy requests can be filed and bankruptcy decisions by The Commercial Court can be brought down against debtors who are still solvent, (ie debtors whose assets are greater than the total amount of their debts). With such bankruptcy conditions, legal certainty and the objective of implementing a bankruptcy law that is fair will be very difficult to achieve.

In addition, Law Number 37 of 2004 pays more attention to and protects the interests of the bankrupt creditors rather than the interests of the bankrupt debtor which should also be protected. This means that Law Number 37 of 2004 should pay attention and provide balanced legal protection both to the interests of creditors and debtors in accordance with the principle of bankruptcy in general, namely the principle of providing benefits and balanced legal protection between creditors and debtors and the principle of encouraging investment and business. ${ }^{12}$

The conditions for bankruptcy as referred to in Article 1 "Faillissements-Verordening", which came into force on November 1, 1906, even though it only gives the possibility to submit a bankruptcy request to a debtor in an inability (Van de voorziening in geval van onvermogen van kooplieden ) or not able to be real (kennelijk onvermogen) so it is in a state of stopping repaying its debts. That is, the debtor has been insolvent (greater than the liabilities of the assets and receivables), ${ }^{13}$ Whereas for debtors who are still solvents (smaller than their liabilities and assets), the Curator should ask the debtor to jointly find a solution to settle their obligations by improving management, one example is that the Curator and debtor conduct an independent audit to find out

\footnotetext{
${ }^{10}$ Loc, cit.

${ }^{11}$ Loc, cit.

${ }^{12}$ https://www.hukumonline.com/pusatdata/detail/320/node/19/undangundang-nomor-4-tahun1998/, accessed on 4 July 2019.

${ }^{13}$ Drs. Geez. R. Soejartin, Commercial Law I and II, Publisher Pradnya Paramita, Jakarta, 2000, p. 263.
} 
the debtor's problem so that the curator is not directly conduct asset acquisition from bankrupt debtors. ${ }^{14}$

\subsection{Reform of the Legal Protection System for Debtors in Bankruptcy Law Politics}

In order to realize the implementation of legal protection for debtors from the rights of separatist creditors related to the execution of bankruptcy carried out by separatist creditors against just debtors, it is necessary to reform the debtor's legal protection system in bankruptcy politics.

In order to realize this idea, bankruptcy law politics should return to the mandate of the five precepts of the Pancasila which requires social justice for all classes of Indonesian people who uphold humanity's values so that they are also able to realize Article 28 D paragraph (1) of the 1945 Constitution so that in the end the mandate as stated in the considerations of the Bankruptcy Act is able to be realized properly. ${ }^{15}$

In order to realize the reorientation of political law values in law related to legal protection for the debtor, several things need to be done, namely:

- Running a bankruptcy system conducted by separatist creditors towards debtors based on Pancasila. The first precept Pancasila wants a balance between the realization of the values of justice, humanity, and legal certainty in order to realize humanitarian law or based on human rights in order to realize social justice for all groups of Indonesian people in various aspects of community life both sociocultural, legal, political, and economy. This includes the implementation of bankruptcy carried out by separatist creditors towards debtors which must also include a balance between justice, certainty, and legal benefits, in addition to containing the principles of respect and guarantee of human rights, so that the implementation of the bankruptcy system conducted by separatist creditors towards the debtor can be fair for the debtor as well as the creditor; and

- In order to realize the view on the first point above, the implementation of the bankruptcy system carried out by the separatist creditor against the debtor must be based on the decision of a judge with permanent powers and also based on the principle of fair consumer protection, and to play the mandate as contained in Article 2 of Act Number 37 of the Year 2004 Concerning Bankruptcy and Suspension of Debt Payment Responsibilities. Article 2 of Law Number 37 of 2004 basically provides pre-conditions for bankruptcy of debtors, while the prerequisites are: 1) Debtor owes at least two creditors; 2) Debtor does not pay any creditor even though the debt is due; and 3) Creditors submit bankrupt applications to the local court. The additional requirement is that bankruptcy can be filed if there are other legal remedies outside the court in advance in order to reach a peaceful settlement of the law between the two parties. There needs to be a review related to the understanding that debt debtors cannot be paid with good ethics to creditors.

\footnotetext{
${ }^{14}$ Loc.cit

15 Jarot Jati Bagus Suseno, The Relevance of Pancasila Values in the Politics of Trade Law in the Era of Globalization, Article submitted at the Dharma Dyaksa FGD on June 12, 2013.
} 
Volume 7 Issue 1, March 2020

Nationally Accredited Journal,

Decree No. B/4130/E5/E5.2.1/2019

\section{Closing}

\subsection{Conclusion}

Based on the various explanations above, it can be concluded several things, namely:

- The existence of Article 55 and Article 56 of Law Number 37 Year 2004 Concerning Bankruptcy and Postponement of Obligations for Debt Payment, has resulted in injustice to debtors in the implementation of bankruptcy against debtors committed by creditors;

- So it needs to be reoriented justice in the implementation of debtor protection in the implementation of bankruptcy to the debtor by the creditor by carrying out a system of debtor protection in the bankruptcy of the debtor based on Pancasila, realizing Article Article 2 of Act Number 37 of 2004 Concerning Bankruptcy and Postponement of Payment Liability Debt by adding other pre-conditions in the form of bankruptcy can be submitted if there has been a legal effort outside the other court in advance to achieve a peaceful settlement of the law between the two parties. There needs to be a review related to the understanding that debt debtors cannot be paid with good ethics to creditors

\subsection{Suggestion}

It is necessary to make a special article which regulates the provisions on debtor protection in the implementation of a bankruptcy system for debtors conducted by creditors in Indonesia, particularly by priferent creditors.

\section{References}

\section{Book}

[1] Geez. R. Soejartin, 2000, Commercial Law I and II, Publisher Pradnya Paramita, Jakarta

[2] Riduan Tobink and Bill Nikholaus, 2003, "Dictionary of Banking Terms", Atalya Rileni Sudeco, Jakarta

[3] Gamers, A. 1990. Black's Law Dictionary. Seventh Edition. Minn: West Group

[4] Hartono, Sunaryati, 1988, Indonesian Economic Development Law. Second Body Mold

[5] Hasan, Alwi, 2007, Big Indonesian Dictionary Fourth Edition. Jakarta: PT. Library Center

[6] J. Satrio, 2001, Law, Engagement, Engagement Born of the Agreement. Bandung: Cira Aditya Bakti

[7] Jarot Jati Bagus Suseno, The Relevance of Pancasila Values in the Politics of Trade Law in the Globalization Era, Article submitted at the Dharma Dyaksa FGD on June 12,2013

[8] National Law Development, Ministry of Justice. Jakarta: Bina Cipta 


\section{JURNAL AKTA}

eISSN : 2581-2114, pISSN: 2406-9426

\section{Constitution}

[1] Code of Civil law

[2] Law Number 4 of 1998 concerning Bankruptcy

[3] Law Number 8 of 1999 concerning Consume Protection

[4] Law No. 37 of 2004 concerning Bankruptcy and Suspension of Debt Payment Obligations

\section{Internet}

[1] Anggar Septiadi, Around 2018, Number of Bankruptcy Cases Soared, accessed via kontan.co.id, on May 12, 2019

[2] https://www.hukumonline.com/pusatdata/detail/320/node/19/undangundangnomor-4-tahun-1998/, accessed on 4 July 2019. 